Article - Agriculture, Agribusiness and Biotechnology

\title{
Arthrographis curvata and Rhodosporidium babjevae as New Potential Fungal Lipase Producers for Biotechnological Applications
}

\author{
Lamya El Aamri ${ }^{1,2 *}$ \\ https://orcid.org/0000-0003-0787-7406
}

\section{Majida Hafidi ${ }^{2}$}

https://orcid.org/0000-0002-6207-2822

\section{Fabio Scordino ${ }^{3}$}

https://orcid.org/0000-0002-7776-8515

\section{Anna Krasowska ${ }^{4}$ \\ https://orcid.org/0000-0002-1925-193X}

\section{Ahmed Lebrihi ${ }^{5}$}

https://orcid.org/0000-0001-8644-5884

\author{
Maria Grazia Orlando ${ }^{1}$ \\ https://orcid.org/0000-0002-3689-4611
}

\author{
Cinzia Barresi ${ }^{1}$ \\ https://orcid.org/0000-0002-5159-5353
}

Giuseppe Criseo ${ }^{1}$

https://orcid.org/0000-0003-4312-513X

\author{
Davide Barreca1 \\ https://orcid.org/0000-0002-1463-4069 \\ Orazio Romeo ${ }^{1,3}$ \\ http://orcid.org/0000-0001-5093-2525
}

${ }^{1}$ University of Messina, Department of Chemical, Biological, Pharmaceutical and Environmental Sciences, Messina, Italy; ${ }^{2}$ Moulay Ismail University, Faculty of Sciences, Department of Biology, Meknes, Morocco; ${ }^{3}$ Center Neurolesi "Bonino-Pulejo", Scientific Institute for Research, Hospitalization and Health Care, Messina, Italy; "University of

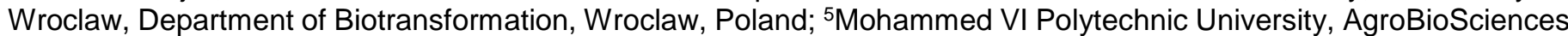
Division, Ben Guerir, Morocco.

Received: 2018.09.17; Accepted: 2020.02.17.

*Correspondence: I.elaamri@edu.umi.ac.ma; Tel.: +212 5355373 21/ 538870 (L.E.)

\section{HIGHLIGHTS}

- This study focused on new extracellular lipase producing fungi

- Identification of the selected lipase-producing fungi was carried out.

- Determination of the lipase production in two different media and different $\mathrm{pHs}$.

- Study of temperature and pH influence on lipase activity.

Abstract: Fungi have always attracted a lot of attention as they are able to produce a vast repertoire of enzymes that find a broad spectrum of uses in biotechnological and industrial fields. Undoubtedly, one of the most promising biocatalysts is the lipase, which has been widely used for the biotransformation of a number of commercial products due to its high stability, high catalytic efficiency, versatility and selectivity, making it one of the most attractive and best-studied enzymes.

In this study we report the isolation and molecular identification of new lipase-producing fungi from different environmental samples from Morocco. The production and activity of extracellular lipases, at different parameters, was evaluated using the Rhodamine B agar, submerged fermentation and biochemical methods. 
Two fungal strains Arthrographis curvata and Rhodosporidium babjevae, were isolated and found to produce large amounts of lipases. The optimal activity of the extracellular lipase was detected at $40^{\circ} \mathrm{C}$ and $\mathrm{pH} 9.0$ for A. curvata and at $40^{\circ} \mathrm{C}$ and $\mathrm{pH} 8.0$ for $R$. babjevae.

This study add new information at the growing list of fungal species producing lipases with improved physicochemical proprieties which could constitute a new line of research for further studies and to be exploited for industrial or bioremediation purposes.

Keywords: Fungal lipases; Lipolytic activity; enzymes; lipolytic fungi; Arthrographis curvata; Rhodosporidium babjevae.

\section{INTRODUCTION}

Lipases (triacylglycerol acyl hydrolases EC 3.1.1.3) are ubiquitous enzymes with high biotechnological and industrial potential that normally act to hydrolyze triacylglycerols into a mixture of free fatty acids and acylglycerols [1,2]. However these enzymes can also successfully catalyze, with high regio- and enantioselectivity, the synthesis of organic compounds by esterification and transesterification reactions in water-restricted media or organic solvents $[3,4]$. The versatility of these natural biocatalysts, including their eco-friendliness and stability, has made lipases remarkably useful in catalyzing numerous processes relevant to the pharmaceutical, cosmetic, leather, paper, food and beverage industries as well as for biodiesel production and bioremediation applications $[5,6,7]$. Farther, lipases serve as a part of the growing interest of biosensors helping in medical diagnostics [8].

Lipases have been found in many species of animals, plants, and microrganisms $[5,9,10,4,11]$ but the ease with which they are isolated from microbes has made both bacteria and fungi the predominant sources of these enzymes [5,4,12].

Fungi are widely recognized as the best producers of extracellular lipases and are preferably used for several industrial applications due to the ease with which these enzymes are recovered from the fermentation broth $[10,13]$. Currently, most of commercially important lipases are produced by yeasts, such as Candida rugosa and Candida antarctica, or by filamentous fungi belonging to different fungal genera such as Mucor, Humicola, Aspergillus, Rhizopus, Geotrichum and Penicillium [5,14]. However, nature offers a big potential for identifying new microbial lipases with novel or better physicochemical properties. In fact, lipolytic fungi can be easily isolated from different natural sources $[10,15,16]$ including polluted environments or industrial and domestic wastes $[5,10,13]$. Therefore many researchers worldwide have tried to obtain new fungal lipases by screening lipid-rich products and/or samples recovered from natural or polluted habitats $[5,16]$ thus stimulating an intensive research that constantly leads to the identification of new lipase producers $[17,18,19]$.

The main objective of the present work was to screen for new lipase-producing fungi collected from different environmental samples from two regions in Morocco: Meknes and Beni Mellal. In this study we report new fungal species capable of producing extracellular lipases in different culture media and $\mathrm{pH}$ values.

\section{MATERIAL AND METHODS}

\section{Environmental samples and fungal isolation}

In this study a total of 27 environmental samples: 11 olive pomace (skins, pulp, seeds and stems of the fruit), 2 black olive, 9 rancid butter, 3 rotten strawberry and 2 rotten orange were collected from two different regions in Morocco: Meknes (coordinates: $33^{\circ} 53^{\prime} 42^{\prime \prime} \mathrm{N}^{\circ} 33^{\prime} 17^{\prime \prime} \mathrm{W}$ ) and Beni Mellal (coordinates: $\left.32^{\circ} 20^{\prime} 22^{\prime \prime} \mathrm{N} \mathrm{6} 6^{\circ} 21^{\prime} 39^{\prime \prime} \mathrm{W}\right)$.

Twenty grams of each sample, except rancid butter, were suspended in $20 \mathrm{ml}$ of sterile saline solution $(0.85 \% \mathrm{w} / \mathrm{v} \mathrm{NaCl})$ and homogenized using a stomacher blender (Pbi international, Italy) for $3 \mathrm{~min}$. Conversely, for rancid butter, $10 \mathrm{~g}$ were added to $10 \mathrm{ml}$ of sterile saline solution and incubated in water bath at $45^{\circ} \mathrm{C}$ for $30 \mathrm{~min}$. After incubation the mixture was homogenized by vortex stirring (30 s) and then left to settle at room temperature until complete separation of the aqueous phase that was used for microbiological analysis.

For all samples, serial ten-fold dilutions were prepared in saline solution and aliquots of $100 \mu \mathrm{l}$ of each suspension were plated in duplicate on malt extract agar (MEA) and Sabouraud dextrose agar (SDA) supplemented with antibiotics (penicillin $20 \mathrm{U} / \mathrm{mL}$ and streptomycin $40 \mathrm{U} / \mathrm{mL}$ ). Inoculated plates were then incubated at $30{ }^{\circ} \mathrm{C}$ and examined daily for up to 7 days for the presence of fungal colonies that were subcultured and purified onto SDA as they appeared. 


\section{Qualitative and quantitative screening for lipase-producing fungi}

All purified fungal strains were screened for their ability to produce extracellular lipases using the rhodamine B agar medium ( $8 \mathrm{~g} \mathrm{~L}^{-1}$ nutrient broth; $4 \mathrm{~g} \mathrm{~L}^{-1} \mathrm{NaCl} ; 10 \mathrm{~g} \mathrm{l}^{-1}$ agar; $31.25 \mathrm{ml} \mathrm{L}^{-1}$ olive oil and $10 \mathrm{~mL}$ rhodamine B solution, final concentration $0.001 \% \mathrm{w} / \mathrm{v} ; \mathrm{pH} 7.0)$.

Ten microliters of each standardized fungal suspension $\left(\sim 20 \times 10^{6}\right.$ cells $\left.\mathrm{ml}^{-1}\right)$ were dispensed into agar wells ( $6 \mathrm{~mm}$ diameter) of the culture medium and plates were incubated at $30^{\circ} \mathrm{C}$ for one week. To detected and monitor lipase production, plates were exposed to UV light (366 nm) and the wells showing an orange fluorescent halo were considered indicative for lipase production by the tested strain. The ratio between the diameters of the halo $(\mathrm{H})$ and wells containing fungi $(w)(H / W$ index) was determined and utilized as a measure of lipase production. An $\mathrm{H} / \mathrm{W}$ value of 1 indicated the absence of lipase production while higher $\mathrm{H} / \mathrm{W}$ values were considered as a signal of lipase secretion. Only fungal strains with $\mathrm{H} / \mathrm{W}$ index comparable to that obtained from a reference strain were selected for further studies.

C. antarctica CBS 6678, whose lipolytic activity was previously well-documented [20], was used as reference strain in all experiments.

\section{Phenotypic and molecular identification of the selected lipase-producing fungal strains}

Only the fungal strains showing high lipase-production levels on rhodamine B agar, comparable to those of the $C$. antarctica CBS 6678 reference strain, were identified at the species level.

Standard phenotypic identification was based on colony appearance on different solid media including macro and micro-morphological characters according to the methods of traditional mycological identification [21,22].

The identity of the fungal strains was subsequently obtained by sequencing the entire ITS region (ITS1$5,8 S$-ITS2) as well as D1/D2 domain of the 28S rDNA of the isolate LE.154 to provide a complete draft for microbial taxonomy. Total genomic DNA was isolated using the glass-beads disruption method followed by conventional phenol/chloroform extraction and ethanol precipitation as described in Müller and coauthors [23].

In vitro amplifications were carried out separately using the DreamTaq ${ }^{\mathrm{TM}} \mathrm{PCR}$ master mix (Fermentas,

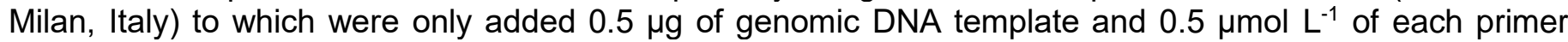
depending on the genetic marker amplified. The PCR primers used for the partial amplification of the 28S rDNA were: NL1-GCATATCAATAAGCGGAGGAAAAG and NL4-GGTCCGTGTTTCAAGACGG [24] whereas the following primers ITS1-TCCGTAGGTGAACCTGCGG and ITS4-TCCTCCGCTTATTGATATGC were used for the amplification of the whole ITS1-5,8S-ITS2 region [25].

The PCR reactions were carried out in a MyCycler thermal cycler (BioRad, Milan, Italy) using the following settings: initial heating to $95^{\circ} \mathrm{C}$ for $5 \mathrm{~min}$, followed by 35 cycles of denaturation at $94^{\circ} \mathrm{C}$ for $1 \mathrm{~min}$, annealing at $52{ }^{\circ} \mathrm{C}(\mathrm{NL}-1 / \mathrm{NL}-4)$ or $55^{\circ} \mathrm{C}$ (ITS1/ITS4) for $60 \mathrm{~s}$ and extension at $72{ }^{\circ} \mathrm{C}$ for $1 \mathrm{~min}(\mathrm{NL}-1 / \mathrm{NL}-4)$ or for $90 \mathrm{~s}$ (ITS1/ITS4), with a final elongation step of $10 \mathrm{~min}$ at $72{ }^{\circ} \mathrm{C}$.

$2 \mu \mathrm{L}$ aliquot of each amplicon was subjected to agarose gel (1.5\%) electrophoresis to confirm the presence of the amplified product. Then, the remaining amount of the PCR product was first purified using the QIAquik PCR purification kit (Qiagen, Milan, Italy) and subsequently sequenced at the Eurofins Genomics, Ebersberg, Germany (www.eurofinsgenomics.eu) using the same PCR primers. Sequencing chromatograms were visually inspected using the FinchTV v1.4 software to detect call errors and then the identity of the obtained nucleotide sequence was assessed by BLAST searches (https://www.ncbi.nlm.nih.gov/BLAST) against the Genbank database for taxonomic recognition of our fungal strains.

\section{Lipase production in submerged culture}

For lipase production, two different culture media were used: the mineral medium $\left(10 \mathrm{~g} \mathrm{~L}^{-1}\right.$ yeast extract; $12 \mathrm{~g} \mathrm{~L}^{-1} \mathrm{Na}_{2} \mathrm{HPO}_{4} ; 2 \mathrm{~g} \mathrm{~L}^{-1} \mathrm{KH}_{2} \mathrm{PO}_{4} ; 0.3 \mathrm{~g} \mathrm{~L}^{-1} \mathrm{MgSO}_{4}-7 \mathrm{H}_{2} \mathrm{O} ; 0.3 \mathrm{~g} \mathrm{~L}^{-1} \mathrm{CaCl}_{2}-\mathrm{H}_{2} \mathrm{O} ; 2 \%$ olive oil; final pH 7.5 \pm 0.2 ) and a complex medium (8 $\mathrm{g} \mathrm{L}^{-1}$ nutrient broth; $4 \mathrm{~g} \mathrm{~L}^{-1} \mathrm{NaCl} ; 2 \%$ olive oil; final $\left.\mathrm{pH} 7.5 \pm 0.2\right)$. For both culture media, we used commercially available extra virgin olive oil.

All components, except olive oil, were autoclaved at $121^{\circ} \mathrm{C}$ for $15 \mathrm{~min}$ and after cooling $\left(\sim 60{ }^{\circ} \mathrm{C}\right)$, the olive oil, sterilized by filtration (filter $0.22 \mu \mathrm{m}$ pore size), was added to the culture media.

Experiments were performed 3 times in duplicate using $100 \mathrm{~mL}$ Erlenmeyer flasks containing $20 \mathrm{ml}$ of liquid medium. The media were inoculated with a standardized fungal suspension $\left(\sim 2 \times 10^{6} \mathrm{cells}^{\mathrm{mL}}{ }^{-1}\right)$ and incubated at $28^{\circ} \mathrm{C}$ for $96 \mathrm{~h}$ in an orbital shaker operating at $180 \mathrm{rpm}$. 
To evaluate the effect of the $\mathrm{pH}$ on the lipase production, additional cultures were done in both mineral and complex liquid media with $\mathrm{pH}$ values of 6.0 and 9.0 respectively.

Two species for which lipase production was previously studied C. antarctica CBS 6678 [20] and Rhodosporidium babjevae BD19 [26] were included as reference strains and used in the comparative analysis.

\section{Crude lipase preparation}

In order to remove fungal cells, the cultures were centrifuged at $12,000 \mathrm{rpm}$ at $4{ }^{\circ} \mathrm{C}$ for $15 \mathrm{~min}$ and supernatants were filtered through $0.22 \mathrm{~mm}$ pore-sized filters. The filtrates were collected and stored at $20^{\circ} \mathrm{C}$ until lipolytic activity assays were performed.

\section{Determination of the lipase and esterase activities using p-nitrophenyl palmitate (p-NPP) and p- nitrophenyl acetate ( $p-N P A)$ as substrates}

For lipase assay, the substrate solution was prepared by adding $100 \mu \mathrm{L}$ of the p-NPP solution $(7.5 \mathrm{mg}$ p-NPP from Sigma Aldrich, Italy, dissolved in $2 \mathrm{~mL}$ of propane-2-ol and acetonitrile 1:1) to $800 \mu \mathrm{L}$ of 0.05 mol L-1 Tris- $\mathrm{HCl}$ buffer ( $\mathrm{pH} 8.0$ ) and $75 \mu \mathrm{L}$ of water. The lipase assay was carried out at $25^{\circ} \mathrm{C}$ in the presence of Triton X-100 (20 $\left.\mu \mathrm{mL}^{-1}\right)$ [27] by adding $25 \mu \mathrm{L}$ of the enzyme extract to the substrate solution. After $20 \mathrm{~min}$, the reaction was stopped by incubating the mixture on ice. The absorbance was spectrophotometrically measured at $405 \mathrm{~nm}$, against an enzyme-free control.

One lipase unit $(U)$ was defined as the amount of enzyme that liberates $1 \mu \mathrm{mol}$ of $p$-nitrophenol per min, under the described assay conditions. All enzyme assays were carried out in double and the average values were calculated.

The eventual unspecific esterase activity was spectrophotometrically determined following the protocol described above but replacing the p-nitrophenyl palmitate with $p$-nitrophenyl acetate (p-NPA) (Sigma Aldrich, Italy) at $25^{\circ} \mathrm{C}$ and $\mathrm{pH} 8.0$.

\section{Effect of the temperature and pH on enzyme activity}

The optimal temperature of the lipase was determined by measuring its activity in $0.05 \mathrm{~mol} \mathrm{~L}^{-1} \mathrm{Tris} \mathrm{HCl}$ $\left(\mathrm{pH}\right.$ 8.0) under temperatures ranging from $25^{\circ} \mathrm{C}$ to $60^{\circ} \mathrm{C}$ with regular increments intervals of $5^{\circ} \mathrm{C}$.

For each strain, the effect of $\mathrm{pH}$ was also determined by measuring lipase activity at its optimum temperature (as established above) using $0.05 \mathrm{~mol} \mathrm{~L}^{-1}$ of the following buffers with different $\mathrm{pH}$ values (ranging from 5 to 11): acetate $(\mathrm{pH} 5.0)$, sodium bicarbonate $(\mathrm{pH} 6.0)$, phosphate $(\mathrm{pH} 7.0)$, Tris- $\mathrm{HCl}(\mathrm{pH} 7.5$ to 10) and sodium phosphate (pH 11.0).

\section{Statistical analysis}

All biochemical and physiological data were analysed with GraphPad prism version 6.0 software (Graphpad Software, Inc., CA, USA) and expressed as mean \pm standard deviation (SD).

\section{RESULTS}

\section{Indentification of lipolityc fungi}

In this study, a total of 107 filamentous fungi (moulds) and 18 yeasts were isolated from the examined environmental samples. The selective rhodamine B medium used for detecting lipolytic strains revealed that only two fungal strains, LE.154 (isolated from rotten strawberry) and LE.170 (isolated from olive pomace), showed a significant orange fluorescence halo comparable to that obtained from the C. antarctica CBS 6678 reference strain when excited by UV light after 6 days of incubation. The H/W ratio (Hydrolysis/Well) for the reference strain $C$. antarctica CBS 6678 was found to be 2.00, whereas for LE.154 strain the value was 2.17 and for LE.170 strain it was 1.83. In contrast, the H/W index value was about 1 for the other isolates. Therefore, only the two strains LE.154 and LE.170 were considered for further analysis. The colonies formed by LE.154 strain resulted red, smooth, glistening and mucoid and microscopic analysis showed the presence of ovoidal cells. No pseudomycelium nor true mycelium was observed in corn meal agar cultures after 7 days of incubation at $25^{\circ} \mathrm{C}$.

In contrast the colonies produced by LE.170 strain on MEA were orange-yellow and on PDA pale to greyish orange with whitish margin, powdery, umbonate at centre and flat toward the periphery. 
Direct microscopic examination showed the presence of unicellular cylindrical arthroconidia, curved, cashew- nut-shaped.

BLAST analysis of the entire ITS region revealed that LE.170 strain had $99 \%$ similarity to Arthrographis curvata and to Arthrographis kalrae.

Conversely, sequence analysis of complete ITS region including the D1/D2 domain of the 28S rDNA of the LE.154 isolate showed $99 \%$ homology to Rhodotorula glutinis, Rhodotorula graminis and Rhodosporidium babjevae indicating that this genetic marker was not sufficient to clearly identify our isolate. However comparison of the nucleotide sequence of D1/D2 with the corresponding sequences of five $R$. glutinis, two $R$. graminis and $18 R h$. babjevae strains published by Kurtzman and coauthors. revealed that a single base mismatch between $R$. glutinis and the pair $R h$. babjevae/R. graminis. And the comparison of ITS1-5,8S-ITS2 region showed that one mismatch and three indels were found to occur between $R$. glutinis and $R$. graminis and three mismatches between $R$. glutinis and $R h$. babjevae [22]. The LE.154 isolate shares the same genetic polymorphisms with $R h$. babjevae and therefore was identified as such by molecular analysis.

The sequences obtained in this work were submitted to Genbank under the accession numbers MN521448 and MN521449 for sequences of ITS region and D1/D2 domain of Rh. babjevae LE.154, respectively, and MN521451 for ITS region of $A$. curvata LE.170.

The type cultures of the two fungal lipase producers isolated in the present study have been deposited in the Westerdijk Fungal Biodiversity Institute (formerly Centraalbureau voor Schimmelcultures, CBS, collection), The Netherlands (www.westerdijkinstitute.nl), under the codes CBS 15207 and CBS 143248 for $R$. babjevae LE.154 and A. curvata LE.170 strains respectively.

\section{Lipase production by $A$. curvata and $R$. babjevae strains in mineral and complex culture media}

Lipase production was evaluated using submerged fermentation and two different culture media. In mineral medium, after $96 \mathrm{~h}$ of incubation at $28^{\circ} \mathrm{C}$, the highest lipase activity was obtained by the reference strain used in this study, C. antarctica CBS 6678 (140.57 $\mathrm{U} \mathrm{ml}^{-1} \pm$ SD 15.04), followed by R. babjevae LE.154 strain (122.0 $\left.\mathrm{U} \mathrm{ml}^{-1} \pm \mathrm{SD} 5.86\right)$ and $A$. curvata LE. 170 strain (115.43 $\left.\mathrm{U} \mathrm{ml}^{-1} \pm \mathrm{SD} 14.79\right)$. The reference strain $R$. babjevae BD19 was the lowest lipase producer (74.29 $\mathrm{U} \mathrm{ml}^{-1} \pm \mathrm{SD} 8.28$ ) (Figure 1).

In contrast, using the complex medium, the maximum lipase activity was observed for the $A$. curvata LE. 170 strain (120.95 $\left.\mathrm{U} \mathrm{ml}^{-1} \pm 3.46\right)$ followed by $C$. antarctica CBS $6678\left(110.86 \mathrm{U} \mathrm{ml}^{-1} \pm 12.68\right), R$. babjevae LE.154 (45.71 $\left.\mathrm{U} \mathrm{ml}^{-1} \pm 5.11\right)$ and BD19 (45.24 $\left.\mathrm{U} \mathrm{ml}^{-1} \pm 2.81\right)$ strains (Figure 1).

When $\mathrm{p}-\mathrm{NPA}$ was used as substrate, no esterase activity was notified (data not shown).

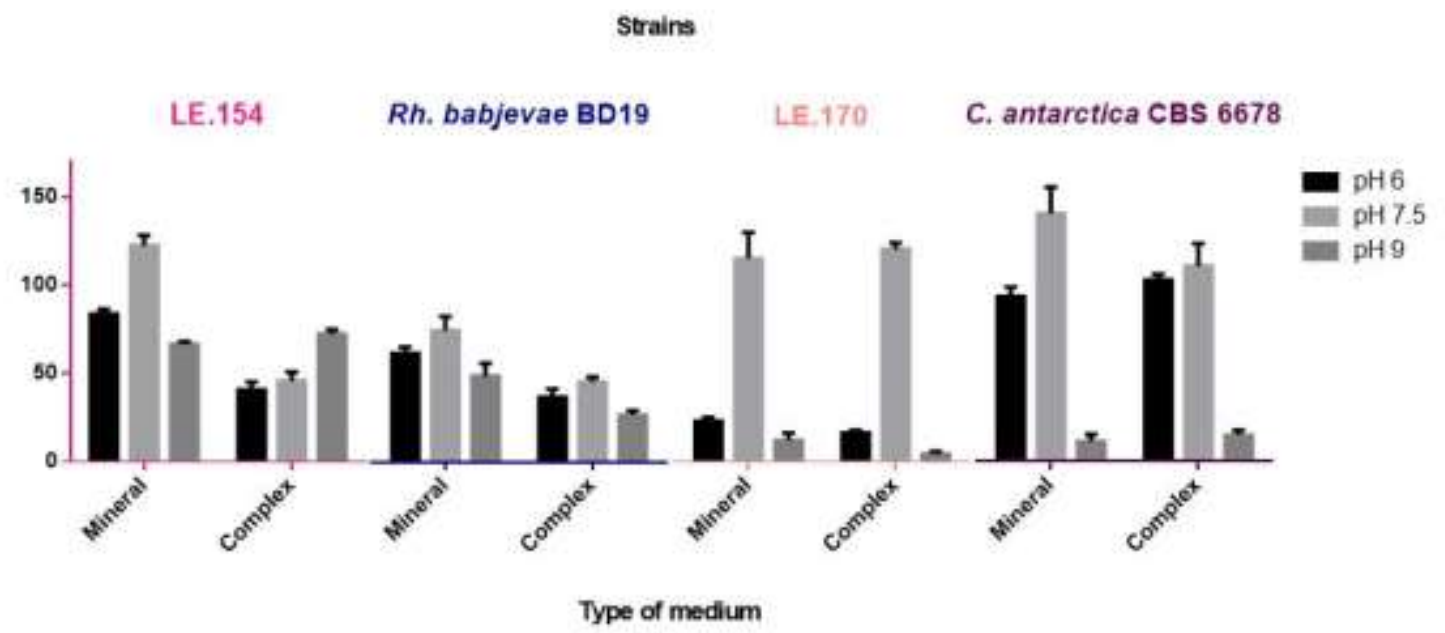

Figure 1. Effect of mineral and complex liquid media and $\mathrm{pH}$ on lipase production. Data are given as means \pm SD.

\section{Lipase production by $A$. curvata and $R$. babjevae strains in culture media with different pHs}

The effect of $\mathrm{pH}$ on lipase production was also investigated by using both mineral and complex liquid media with two different $\mathrm{pH}$ values each, 6.0 and 9.0. Overall, except for the $R$. babjevae LE.154 strain, for each medium we observed a maximum of lipase production when the initial pH was adjusted to 7.5 (Figure 1). Only the $R$. babjevae LE.154 strain showed an increase of the lipase production in the complex medium at $\mathrm{pH} 9.0$ while in mineral medium, the maximum production was observed at $\mathrm{pH} 7.5\left(122.29 \mathrm{U} \mathrm{ml}^{-1} \pm 5.85\right)$ 
and decreased by $31 \%$ and $46 \%$ when the pHs were 6 and 9 respectively (Figure 1). On the contrary, the $A$. curvata LE. 170 strain showed a strong lipase production at $\mathrm{pH} 7.5$ in both culture media used but it lost $80 \%$ and $89 \%$ of its capacity of lipase production in mineral medium and $86 \%$ and $96 \%$ in the complex one when pHs were 6.0 and 9.0 respectively (Figure 1).

The reference strain $R$. babjevae BD19 was the lowest lipase producer in both mineral and complex media at $\mathrm{pH} 7.5$ (Figure 1) while $C$. antarctica CBS 6678 showed a very high production in mineral (140.57 $\left.\mathrm{U} \mathrm{ml} l^{-1} \pm 15.04\right)$ and complex $\left(110.86 \mathrm{U} \mathrm{ml}^{-1} \pm 12.68\right)$ media at the same $\mathrm{pH}$ value. The lipase production declined drastically at $\mathrm{pH} 9$ in both media ( $92 \%$ and $87 \%$ in mineral and complex media respectively) but not at $\mathrm{pH} 6.0$ (Figure 1).

\section{Influence of the temperature and $\mathrm{pH}$ on lipase activity}

In this study both $A$. curvata LE.170 and $R$. babjevae LE.154 extracts showed an optimum temperature for enzyme activity at $40{ }^{\circ} \mathrm{C}$ (Figure 2). For the R. babjevae LE.154 strain, the lipase activity decreased with the increase of the temperature with $24 \%$ of residual enzyme activity at $60{ }^{\circ} \mathrm{C}$. Conversely, the enzymatic activity observed for the $A$. curvata LE.170 strain showed an excellent thermo-stability up to $60^{\circ} \mathrm{C}$ showing a loss of only $19 \%$ of activity.

The lipase extracts from the reference strain $R$. babjevae BD19 showed an optimum of activity at $30{ }^{\circ} \mathrm{C}$ whereas the $C$. antarctica CBS 6678 was highly active at high temperatures with an optimum of activity at $55^{\circ} \mathrm{C}$. However $60 \%$ of lipase activity was lost at $25^{\circ} \mathrm{C}$ (Figure 2 ).

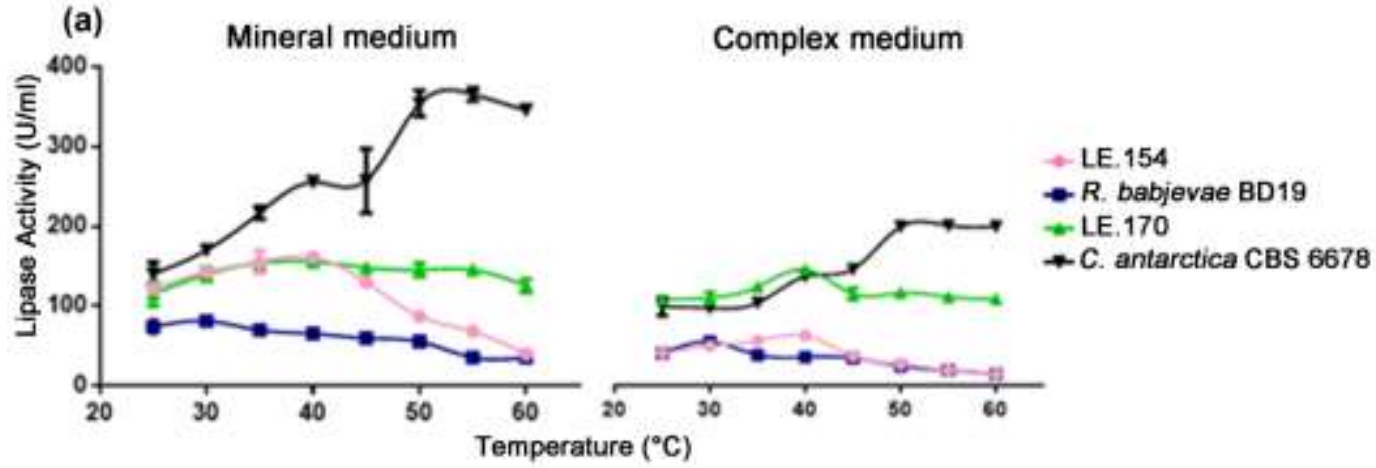

(b)

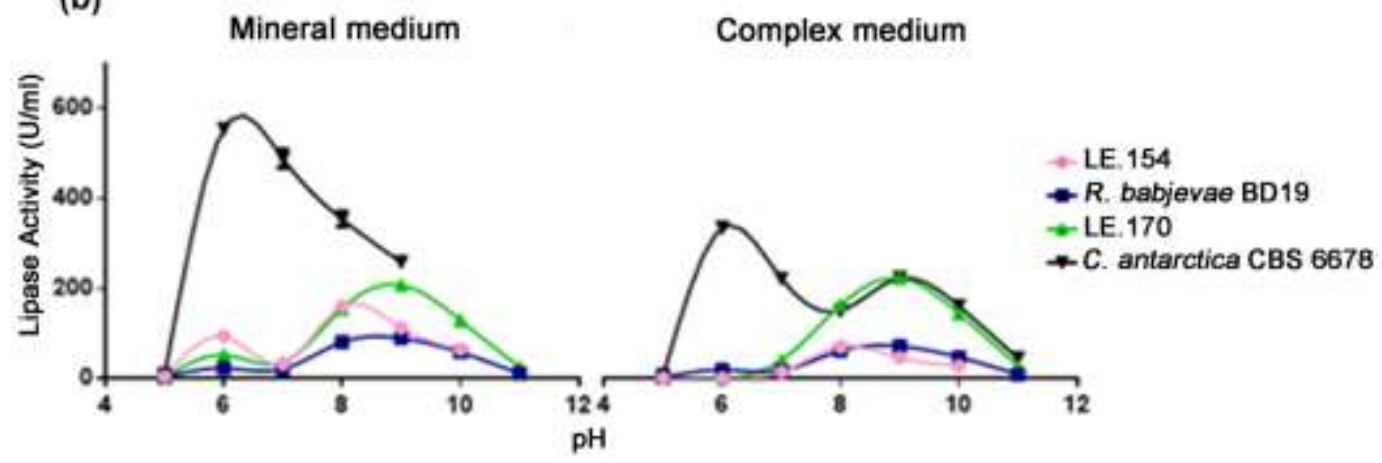

Figure 2. Influence of the temperature (a) and $\mathrm{pH}$ at optimum temperature (b) on lipase activity of the fungal strains grown in mineral and complex media. Data are given as means \pm SD.

To test the influence of $\mathrm{pH}$ on lipase activity, the temperatures to which enzymatic reactions were carried out were chosen according to the results shown above. Consequently the temperature of $40^{\circ} \mathrm{C}$ was used for testing the $A$. curvata LE. 170 and $R$. babjevae LE. 154 strains while the temperatures of $30^{\circ} \mathrm{C}$ and $55^{\circ} \mathrm{C}$ were chosen for the reference strains DB19 and CBS 6678 respectively.

Overall, except for the CBS 6678 strain, the highest enzymatic activities were observed in alkaline conditions (Figure 2). Only C. antarctica CBS 6678 showed an optimum activity at pH 6.0 in both media used. However, we also observed the presence of an additional peak of activity at pH 9.0 when the reference strain was grown in the complex medium (Figure 2).

For the $R$. babjevae LE.154 strain, the highest lipase activity was recorded at pH 8 in both culture media tested and an additional peak of activity was observed at $\mathrm{pH} 6.0$ in mineral medium (Figure 2).

For the A. curvata LE.170 and $R$. babjevae DB19 strains, the maximum values were reached at pH 9.0. Also in this case, for both strains we noted other peaks of activity at $\mathrm{pH} 6.0$ when the lipase production was 
realized in mineral medium (Figure 2). The existence of these double peaks may be probably due to the presence of enzyme isoforms in our extracts.

\section{DISCUSSION}

The potential biotechnological application of fungal metabolism has been recognized since ancient times and still represents an invaluable resource for numerous industrial processes, ranging from the preparation of traditional fermented foods to the production of high-value compounds [28]. In this context, fungal lipases have become the most studied group of biocatalysts as they possess a remarkable ability to carry out a wide variety of chemo-, regio-, and enantioselective transformations making them particularly attractive for many applications in the chemical, pharmaceutical and biomedical sectors [5,13,7].

In the present work, the selective rhodamine B medium for detecting lipolytic strains was used. The formed halos after incubation were easy to identify, since the binding of rhodamine B dye and fatty acids and di- or monoglycerols produces an orange fluorescent complex, clearly and immediately visible under UV irradiation. Two fungal strains LE.154 and LE.170, showed a significant orange fluorescence halo comparable to that obtained from the $C$. antarctica CBS 6678 reference strain. This used method of screening for lipaseproducing microorganisms was reported for the first time by Kouker and Jaeger [29]. Since then, this method has been used by Castro-Ochoa and coauthors [30] and many others [31,32,33,34], this procedure has proved to be highly sensitive and reliable.

BLAST analysis of the entire ITS region revealed that LE.170 strain had $99 \%$ similarity to Arthrographis curvata and to Arthrographis kalrae. The microscopic examination showed curved and cashew- nut-shaped arthroconidia, a feature characterizing $A$. curvata over $A$. kalrae [35]. The latter is known to have cylindrical with truncate arthroconidia [35]. Therefore, the strain LE.170 was identified as A. curvata.

The comparison of the nucleotide sequence of D1/D2 with the corresponding sequences of five $R$. glutinis, two $R$. graminis and $18 R h$. babjevae strains published by Kurtzman and coauthors revealed that a single base mismatch between $R$. glutinis and the pair $R h$. babjevae/R. graminis [22]. And the comparison of ITS1-5,8S-ITS2 region showed that one mismatch and three indels were found to occur between $R$. glutinis and $R$. graminis and three mismatches between $R$. glutinis and $R h$. babjevae [22]. Using Mega 7 software for the comparison of our sequence of LE.154 isolate with different type material strains used by Kurtzman and coauthors [22], the LE.154 isolate shares the same genetic polymorphisms with $R h$. babjevae and therefore was identified as such by molecular analysis.

In this study, $A$. curvata was added to the growing list of fungal lipases producers $[5,17,18,19]$ by highlighting that the production of this enzyme, from the studied strain appears to be independent of the type of fermentation medium used (Figure 1). In addition, the lipase from $A$. curvata LE.170 strain showed an excellent thermo-stability (up to $60^{\circ} \mathrm{C}$ ) with a pH-optimum of activity at 9.0, making it potentially suitable for the bioindustry and/or for the bioremediation of agri-food waste with high fat content.

The optimum $\mathrm{pH}$ for lipase production is extremely variable among fungi, being related to the genus, species and even to the strain. In fact it varies between 3.0 and 7.0 for members belonging to the Geotrichum genus [36], to $\mathrm{pH}$ 4.0-9.0 for Penicillium [37] and pH 5.0-8.0 for Rhizopus species [38]. However, species that produce extracellular lipases which are also stable at relatively high alkaline conditions and high temperatures are rarely isolated [5] and therefore the $A$. curvata lipase could be a good candidate for industrial applications according to the intrinsic physicochemical characteristics observed.

In this study, an additional fungal lipase producer $R$. babjevae, was isolated from rotten strawberry. However, one strain of this species ( $R$. babjevae BD19) was already previously reported to produce an extracellular lipase [26] and the data obtained from the present study confirmed that this fungus is able to secrete a versatile enzyme whose activity appears to be strain-dependent as well as related to the type of culture medium used (Figures 1 and 2). This is also well-supported by Lukaszewicz and coauthors [26] and could be related to the different environments from which LE.154 (rotten strawberry) and the BD19 strain (freshwater from Arctic Archipelago of Svalbard) [26] were isolated. Interestingly, the lipase from R. babjevae seems to have a specific regiospecificity among all existing fungal lipases $[26,39]$ as it cleaves the triglyceride triolein only once in position 1 releasing two products: 1,2 (or -2,3)-diolein and free fatty acid [26]. This unique characteristic, including the high lipase activity observed in mineral medium, could be of biotechnological interest for the design and synthesis of specific high-value molecules.

In this study, for the R. babjevae LE.154 strain, as well as for A. curvata, the presence of two distinct peaks was detected during the evaluation of the $\mathrm{pH}$ effect on lipase activity (Figure 2) indicating that these species were able to produce mixtures of lipase isoforms with different catalytic and regulatory properties like other commercially available fungal lipase producers [40,41]. This could be of great scientific value and serve as a good reference for future genetic and expression studies of the regulatory pathways controlling the 
lipase-genes transcription in these new producers, resulting in high industrial and biotechnological applications.

\section{CONCLUSION}

Industrial demands for lipase are increasing and bacterial lipases are the most used for biotechnological purposes. Comparing to bacteria, less number of fungi species have been studied for lipase production and potential biotechnological applications. In this work, we showed that two isolates obtained from analyzed environmental samples; olive pomace and rotten strawberry, identified as Rhodosporidium babjevae and Arthrographis curvata, were able to produce lipase using different complex and mineral liquid media, and which can be used for numerous biotechnological applications. We showed as well variable profiles of lipase production and activity of one of the strains compared to the same species, but both were isolated in different corner of the world; activities were strain dependent.

By contrast, the presence of lipase producing fungi in olive pomace could negatively influences the quality of olive pomace oil through increasing its acidity, causing damage to olive oil companies. However, the olive pomace could have immense benefits by reducing the cost of lipase production through solid state fermentation.

\section{REFERENCES}

1. Casas-Godoy L, Duquesne S, Bordes F, Sandoval G, Marty A. Lipases: an overview. Methods Mol Biol. 2012; 861: 3-30. https://doi.org/10.1007/978-1-61779-600-5_1

2. Tortora GJ, Funke BR, Case CL. Microbiology: an introduction. vol 9. 13 th Edition. San Francisco, USA :Benjamin Cummings; 2019. 827 pp. LCCN Permalink: https://lccn.loc.gov/2017044147

3. Alnoch RC, Martini VP, Glogauer A, Costa AC, Piovan L, Muller-Santos M, De Souza EM, De Oliveira Pedrosa F, Mitchell DA, Krieger N. Immobilization and characterization of a new regioselective and enantioselective lipase obtained from a metagenomic library. PLoS One. 2015; 10.https://doi.org/10.1371/journal.pone.0114945

4. Javed S, Azeem F, Hussain S, Rasul I, Siddique MH, Riaz M, Afzal M, Kouser A, Nadeem H. Bacterial lipases: A review on purification and characterization. Prog Biophys Mol Biol. 2017; 132: $23-34$. https://doi.org/10.1016/j.pbiomolbio.2017.07.014

5. Singh AK, Mukhopadhyay M. Overview of fungal lipase: a review. Appl Biochem Biotechnol. 2012; 166: 486-520. Doi: 10.1007/s12010-011-9444-3

6. Agobo KU, Arazu VA, Uzo K, Igwe CN. Microbial Lipases: A Prospect for Biotechnological Industrial Catalysis for Green Products: A Review. Ferment Technol. 2017; 6: 2. DOI: 10.4172/2167-7972.1000144

7. Sarmah N, Revathi D, Sheelu G, Yamuna Rani K, Sridhar S, Mehtab V, Sumana C. Recent advances on sources and industrial applications of lipases. Biotechnol Prog. 2018; 34: 5-28. DOI 10.1002/btpr.2581

8. Pohanka M. Biosensors and bioassays based on lipases, principles and applications, a review. Molecules. 2019; 24: 616. https://doi.org/10.3390/molecules24030616

9. Seth S, Chakravorty D, Dubey VK, Patra S. An insight into plant lipase research-challenges encountered. Protein Expr Purif. 2014; 95: 13-21. https://doi.org/10.1016/j.pep.2013.11.006

10. Sharma AK, Sharma V, Saxena J. Enhancement of Extracellular Lipase Production by Strain Improvement of Fungus Aspergillus niger LPF-5. Int J Sci Res Environ Sci. 2016; 4:145-152. doi:10.12983/ijsres-2016-p0145-0152

11. Melani NB, Tambourgi EB, Silveira E. Lipases: From Production to Applications. Sep Purif Rev. 2019; 00: 1-16. https://doi.org/10.1080/15422119.2018.1564328

12.Nema A, Patnala SH, Mandari V, Kota S, Devarai SK. Production and optimization of lipase using Aspergillus niger MTCC 872 by solid-state fermentation. Bull Natl Res Cent. 2019; 43: 82. doi:10.1186/s42269-019-0125-7

13. Gopinath SC, Anbu P, Lakshmipriya T, Hilda A. Strategies to characterize fungal lipases for applications in medicine and dairy industry. Biomed Res Int. 2013; 2013:10. http://dx.doi.org/10.1155/2013/154549

14.Barriuso J, Vaquero ME, Prieto A. Martínez traits and catalytic versatility of the lipases from the Candida rugosa-like family: A review. Biotechnol Adv. 2016; 34: 874-885. https://doi.org/10.1016/j.biotechadv.2016.05.004

15.Sadati R, Barghi A, Abbasi Larki R. Isolation and Screening of Lipolytic Fungi From Coastal Waters of the Southern Caspian Sea (North of Iran). Jundishapur J Microbiol. 2015; 8(4). http://dx.doi.org/10.5812/jjm.8(4)2015.16426

16. Sibanda T, Selvarajan R, Tekere M, Nyoni H, Meddows-Taylor S. Potential biotechnological capabilities of cultivable mycobiota from carwash effluents. Microbiologyopen. 2017; 6. doi: 10.1002/mbo3.498

17.Pereira MG, Vici AC, Facchini FDA, Tristão AP, Cursino-Santos JR, Sanches PR, Jorge JA, Polizeli MLTM. Screening of filamentous fungi for lipase production:Hypocrea pseudokoningiia new producer with a high

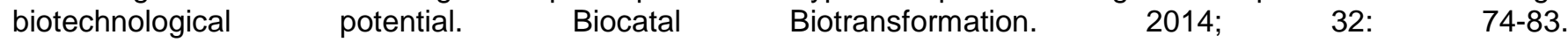
http://dx.doi.org/10.3109/10242422.2013.873417

18. El-Ghonemy DH, El-Gamal M, Tantawy AE, Ali TH. Extracellular Alkaline Lipase from a Novel Fungus Curvularia sp. DHE 5: Optimization of Physicochemical Parameters, Partial Purification and Characterization. Food Technol Biotechnol. 2017; 55. https://doi.org/10.17113/ftb.55.02.17.4958

19. Vyas S, Chhabra M. Isolation, identification and characterization of Cystobasidium oligophagum JRC a cellulase and lipase producing oleaginous yeast. Bioresour Technol. 2017; 1: 250-258. Doi: 10.1016/j.biortech.2016.10.039 
20.Tanino T, Ohno T, Aoki T, Fukuda H, Kondo A. Development of yeast cells displaying Candida antarctica lipase B and their application to ester synthesis reaction. Appl Microbiol Biotechnol. 2007; 75: 1319-1325. Doi: 10.1007/s00253-007-0959-z.

21.Pitt JI, Hocking AD. Fungi and Food Spoilage. $3^{\text {rd }}$ edition. Dordrecht, Heidelberg, London, New York: Springer; 2009. 519 pp. Doi: 10.1007/978-0-387-92207-2

22.Kurtzman, C.P.; Fell, J.W.; Boekhout, T. The Yeasts, a taxonomic study. Volume 1. 5th edition. Amsterdam, The Netherlands: Elsevier Science; 2011. 1902 pp. ISBN: 978-0-444-52149-1

23. Müller FM, Werner KE, Kasai M, Francesconi A, Chanock SJ, Walsh TJ. Rapid Extraction of Genomic DNA from Medically Important Yeasts and Filamentous Fungi by High-Speed Cell Disruption. J Clin Microbiol. 1998; 36: 16251629. PMID: 9620390

24.Kurtzman C, Robnett C. Identification of clinically important ascomycetous yeasts based on nucleotide divergence in the 5' end of the large-subunit (26S) ribosomal DNA gene. J Clin Microbiol. 1997; 35: 1216-1223. PMID: 9114410

25. White TJ, Bruns T, Lee S, Taylor JW. Amplification and direct sequencing of fungal ribosomal RNA genes for phylogenetics. Innis MA, Gelfand DH, Sninsky JJ, White TJ, eds. PCR Protocols: A Guide to Methods and Applications. New York, USA: Academic Press Inc; 1990. p. 315-322. http://dx.doi.org/10.1016/B978-0-12-3721808.50042-1

26.Lukaszewicz M, Jablonski S, Krasowska A. Characterisation of Alkaline Lipase From an Arctic Yeast Strain Rhodosporidium babjevae Bd19. Eur Sci J. 2013 ; 3 : 24-26.

http://www.eujournal.org/index.php/esj/article/view/1480

27. Gupta N, Rathi P, Gupta R. Simplified para-nitrophenyl palmitate assay for lipases and esterases. Anal Biochem. 2002; 311: 98-99. DOI: 10.1016/S0003-2697(02)00379-2

28.Steensels J, Snoek T, Meersman E, Picca Nicolino M, Voordeckers K, Verstrepen KJ. Improving industrial yeast strains: exploiting natural and artificial diversity. FEMS Microbiol Rev. 2014; 38: 947-995. Doi: 10.1111/15746976.12073

29. Kouker G, Jaeger K. Specific and Sensitive Plate Assay for Bacterial Lipases. Appl Environ Microbiol. 1987; 53: 211213. Doi: 0099-2240/87/010211-03\$02.00/0

30. Castro-Ochoa LD, Rodríguez-Gómez C, Valerio-Alfaro G, Oliart Ros R. Screening, purification and characterization of the thermoalkalophilic lipase produced by Bacillus thermoleovorans CCR11. Enzyme Microb Technol. 2005; 37: 648-654. https://doi.org/10.1016/j.enzmictec.2005.06.003

31. Kumar D, Kumar L, Nagar S, Raina C, Parshad R, Gupta VK. Screening, isolation and production of lipase/esterase producing Bacillus sp. strain DVL2 and its potential evaluation in esterification and resolution reactions. Arch Appl Sci Res. 2012; 4: 1763-1770. CODEN (USA) AASRC9

32. Ramnath L, Sithole B, Govinden R. Identification of lipolytic enzymes isolated from bacteria indigenous to Eucalyptus wood species for application in the pulping industry. Biotechnol Reports. 2017; 15: 114-124. http://dx.doi.org/10.1016/j.btre.2017.07.004

33.Salwoom L, Rahman R, Abd Zaliha R, Noor Salleh AB, Convey P, Pearce D, Ali M, Shukuri M. Isolation, Characterisation, and Lipase Production of a Cold-Adapted Bacterial Strain Pseudomonas sp. LSK25 Isolated from Signy Island, Antarctica. Molecules. 2019; 24: 715. https://doi.org/10.3390/molecules24040715

34. Priyanka P, Kinsella G, Henehan GT, Ryan BJ. Isolation, purification and characterization of a novel solvent stable lipase from Pseudomonas reinekei. Protein Expr Purif. 2019; 153: 121-130. https://doi.org/10.1016/j.pep.2018.08.007

35. Giraldo A, Gené J, Sutton DA, Madrid H, Cano J, Crous PW, Guarro J. Phylogenetic circumscription of Arthrographis (Eremomycetaceae, Dothideomycetes). Persoonia Mol Phylogeny Evol Fungi. $2014 ; 32: 102$. http://dx.doi.org/10.3767/003158514X680207

36. Maldonado RR, Lopes DB, Aguiar-Oliveira E, Kamimura ES, Macedo GA. A Review on Geotrichum Lipases: Production, Purification, Immobilization and Applications. Chem Biochem Eng Q J. 2016; 30: $439-454$. https://doi.org/10.15255/CABEQ.2016.907

37.Li N, Zong MH. Lipases from the genus Penicillium: Production, purification, characterization and applications. J Mol Catal B Enzym. 2010; 66: 43-54. https://doi.org/10.1016/j.molcatb.2010.05.004

38. Yu XW, Xu Y, Xiao R. Lipases from the genus Rhizopus: characteristics, expression, protein engineering and application. Prog Lipid Res. 2016; 64: 57-68. Doi: 10.1016/j.plipres.2016.08.001

39. Kapoor M, Gupta MN. Lipase promiscuity and its biochemical applications. Process Biochem. 2012 ; $47: 555-569$. https://doi.org/10.1016/j.procbio.2012.01.011

40.Domínguez de María P, Sánchez-Montero JM, Sinisterra JV, Alcántara AR. Understanding Candida rugosa lipases: An overview. Biotechnol Adv. 2006; 24: 180-196. https://doi.org/10.1016/j.biotechadv.2005.09.003

41. Margesin R, Feller G. Biotechnological applications of psychrophiles. Env Technol. 2010; 31: 835-844. https://doi.org/10.1080/09593331003663328

(C) 2020 by the authors. Submitted for possible open access publication under the terms and conditions of the Creative Commons Attribution (CC BY NC) license (https://creativecommons.org/licenses/by-nc/4.0/). 